\title{
Mineralization of Drugs in Aqueous Medium by Advanced Oxidation Processes
}

\author{
José Antonio Garrido,* Enric Brillas, Pere Lluís Cabot, Francesc Centellas, \\ Conchita Arias, Rosa María Rodríguez
}

Laboratori d'Electroquímica dels Materials i del Medi Ambient, Departament de Química Física, Facultat de Química, Universitat de Barcelona, Martí i Franquès 1-11, 08028 Barcelona, Spain

\begin{abstract}
At present chemical (AOPs) and electrochemical (EAOPs) advanced oxidation processes with ability to destroy organic pollutants in waters are being developed. These methods are based on the production of hydroxyl radical $\left({ }^{\circ} \mathrm{OH}\right)$ as oxidant. In AOPs ${ }^{\circ} \mathrm{OH}$ radical can be obtained from Fenton's reaction between $\mathrm{Fe}^{2+}$ and $\mathrm{H}_{2} \mathrm{O}_{2}$ added to the medium, photoreduction of $\mathrm{Fe}^{3+}$ species or reaction between ozone and $\mathrm{Fe}^{2+}$. In EAOPs this radical is formed from water oxidation on the surface of a high $\mathrm{O}_{2}$-overvoltage anode and/or Fenton's reaction between $\mathrm{Fe}^{2+}$ added to the medium and $\mathrm{H}_{2} \mathrm{O}_{2}$ electrogenerated at the cathode by the two-electron reduction of oxygen. The present work reports the mineralization of several aromatic drugs such as paracetamol, ibuprofen, clofibric acid and salicylic acid by AOPs based on ozonation catalyzed by $\mathrm{Fe}^{2+}, \mathrm{Cu}^{2+}$ and/or UVA light and EAOPs like anodic oxidation, electro-Fenton and photoelectro-Fenton, which are environmentally friendly electrochemical methods. For the latter processes, the drug decay with time and the evolution of aromatic intermediates and generated carboxylic acids are studied. Anodic oxidation is only effective when a boron-doped diamond (BDD) anode is used, whereas the photoelectroFenton process with $\mathrm{Fe}^{2+}, \mathrm{Cu}^{2+}$ and UVA light is the most potent method to completely destroy the drugs. The combined use of catalysts $\mathrm{Fe}^{2+}, \mathrm{Cu}^{2+}$ and UVA light in catalyzed ozonation also leads to overall decontamination of drug solutions.
\end{abstract}

Keywords: drugs, ozonation, catalysis, anodic oxidation, boron-doped diamond electrode, electro-Fenton, photoelectro-Fenton.

\footnotetext{
* Corresponding author. E-mail address: joseagarrido@ub.edu.
} 


\section{Introduction}

Water is a limited resource that continuously recirculates through all the aquatic environments following a natural cycle. The increasing lack and contamination of this natural resource in many places of the world is alarming and demands urgent solutions. Recently, there is great interest in the environmental relevance of contamination of natural waters by pharmaceutical drugs and their metabolites as emerging pollutants. This pollution can be due to different sources involving emission from production sites, direct disposal of overplus drugs in households, excretion after drug administration to humans and animals, treatments throughout the water in fish and other animal farms and inadequate treatment of manufacturing waste. Since thousands of tons of drugs are consumed each year in the world, a large number of anti-inflammatories, analgesics, antiepileptics, lipid regulators, ß-blockers, antibiotics, estrogens, antiseptics and disinfectants has been detected in sewage treatment plant effluents, in surface and ground waters and even in drinking water at concentration usually ranging from nanograms to micrograms per liter. For example, concentrations of the antiinflammatory paracetamol ( $N$-(4-hydroxyphenyl)acetamide) up to $10 \mu \mathrm{g} \mathrm{L}^{-1}$ in US natural waters and up to $6 \mu \mathrm{g} \mathrm{L}^{-1}$ in effluents of European sewage treatment plants have been detected [1-3]. To avoid the dangerous accumulation of drugs in the aquatic environment, research efforts are underway to develop powerful oxidation methods that can be applied to ensure their complete destruction from natural waters and wastewaters. Although different isolation, physical separation, biological and chemical methods can be utilized [4], the most promising techniques are the so-called advanced oxidation processes based on the in situ generation of hydroxyl radical $\left({ }^{\circ} \mathrm{OH}\right)$ as oxidant of the organic matter [5].

\section{Advanced oxidation processes (AOPs)}

Direct chemical oxidation with $\mathrm{H}_{2} \mathrm{O}_{2}$ or ozone is usually not effective for the treatment of most wastewaters containing organic pollutants. The alternative use of advanced oxidation processes (AOPs) in which ${ }^{\circ} \mathrm{OH}$ is produced by means of chemical, photochemical, photocatalytic or electrochemical reactions is preferred. This radical, the second strongest oxidizing species known after fluorine, reacts non-selectively with most organics leading to dehydrogenated or hydroxylated derivatives until their total mineralization (i.e. their conversion into $\mathrm{CO}_{2}$, inorganic ions and water). However, the oxidation power of ${ }^{\circ} \mathrm{OH}$ in aqueous medium is limited by its low diffusion and reaction with inorganic anions (scavengers) present in wastewaters.

Among the chemical, photochemical and photocatalytic AOPs, the most usual procedures are UV photolysis [6], $\mathrm{H}_{2} \mathrm{O}_{2} / \mathrm{UV}$ [7-9], $\mathrm{O}_{3} / \mathrm{UV}[10,11], \mathrm{O}_{3} / \mathrm{H}_{2} \mathrm{O}_{2} / \mathrm{UVA}$ [12-14], $\mathrm{O}_{3} / \mathrm{Fe}^{2+} / \mathrm{UVA} \quad[15-18], \quad \mathrm{H}_{2} \mathrm{O}_{2} / \mathrm{Fe}^{2+}$ (Fenton's reagent) and $\mathrm{H}_{2} \mathrm{O}_{2} / \mathrm{Fe}^{2+} / \mathrm{UVA}$ (photo-Fenton method) [19-21]. Fenton's reagent is an acidic solution of $\mathrm{H}_{2} \mathrm{O}_{2}$ and a $\mathrm{Fe}^{2+}$ salt that generates $\mathrm{OH}$ and $\mathrm{Fe}^{3+}$ from Fenton's reaction: 


$$
\mathrm{Fe}^{2+}+\mathrm{H}_{2} \mathrm{O}_{2} \rightarrow \mathrm{Fe}^{3+}+\cdot \mathrm{OH}+\mathrm{OH}^{-}
$$

This catalytic reaction propagates from $\mathrm{Fe}^{2+}$ regeneration by reduction of $\mathrm{Fe}^{3+}$, mainly with $\mathrm{H}_{2} \mathrm{O}_{2}$. The catalytic capacity of $\mathrm{Fe}^{2+}$ increases when the solution is irradiated with UVA light of wavelength between 300 and $420 \mathrm{~nm}$ due to: (i) the photolysis of $\mathrm{Fe}^{3+}$ complexes with degradation products such as oxalic acid [19], and (ii) the increase of the regeneration rate of $\mathrm{Fe}^{2+}$ from the additional photoreduction of $\mathrm{Fe}(\mathrm{OH})^{2+}$, the main $\mathrm{Fe}^{3+}$ species in acid medium, from the following photo-Fenton reaction $[20,21]$ :

$$
\mathrm{Fe}(\mathrm{OH})^{2+}+h v \rightarrow \mathrm{Fe}^{2+}+{ }^{\cdot} \mathrm{OH}
$$

\section{Electrochemical advanced oxidation processes (EAOPs)}

Recently, alternative electrochemical methods are being applied to achieve the total degradation of wastewaters containing organics. They are based on: (i) direct electrolysis, where pollutants are removed either by direct electron transfer at the electrode or through their chemical reaction with generated species that remain adsorbed on the electrode surface and (ii) indirect electrolysis, where pollutants are destroyed in the bulk solution by active species generated in the electrode.

The advantages of the electrochemical methods with respect to the chemical ones are: (i) environmental compatibility, since the used reagent is the electron, (ii) versatility, because pollutants can be treated using different reactors and electrode materials of distinct forms and configurations and, in addition, processes can be easily scaled from laboratory to plant, (iii) security, given the mild operative conditions employed and the small amounts of generally innocuous chemicals used, and (iv) energy efficiency, since electrochemical processes are made at low pressure and temperature (environmental conditions), using equipment and simple operations with low cost.

\section{Direct electrolysis}

Anodic oxidation is the most common direct electrochemical method [22-26] applied to water remediation. It is based on the use of high $\mathrm{O}_{2}$-overvoltage anodes favoring the generation of hydroxyl radical as intermediate of the direct water oxidation to oxygen, which remains adsorbed at the anode surface:

$$
\mathrm{H}_{2} \mathrm{O} \rightarrow{ }^{\circ} \mathrm{OH}_{(\mathrm{ads})}+\mathrm{H}^{+}+\mathrm{e}^{-}
$$

The method is carried out generally in the anodic compartment of a divided cell, where the contaminated aqueous solution is degraded using anodes of $\mathrm{Pt}$, undoped and doped $\mathrm{PbO}_{2}$, doped $\mathrm{SnO}_{2}, \mathrm{IrO}_{2}$, etc. Most organic pollutants are then oxidized by ${ }^{\circ} \mathrm{OH}$ electrogenerated at high anode potentials in the region of water discharge with simultaneous evolution of $\mathrm{O}_{2}$, thus causing the regeneration of the anode surface. Under these conditions, however, many solutions are poorly decontaminated by such conventional anodes due to the formation of short-chain 
carboxylic acids that are hardly oxidizable with ${ }^{\circ} \mathrm{OH}$. Recent studies have shown that the latter products can be destroyed using a boron-doped diamond (BDD) thin-film anode with greater $\mathrm{O}_{2}$-overpotential that produces much higher amount of reactive ${ }^{\circ} \mathrm{OH}$ able to react with adsorbed organics up to their complete mineralization. It has been shown that the use of $\mathrm{Pt}[22,23], \mathrm{Ti} / \mathrm{IrO}_{2}$ [27] and $\mathrm{Ti} / \mathrm{RuO}_{2}$ [28] anodes in anodic oxidation favors the electrochemical conversion of pollutants, whereas the alternative treatment with $\mathrm{PbO}_{2}[29,30], \mathrm{Ti} / \mathrm{SnO}_{2}$ $[30,31]$ and BDD $[32,33]$ anodes leads to their electrochemical combustion. This different behavior has been explained by Comninellis and De Battisti [28] for a metallic oxide $\left(\mathrm{MO}_{\mathrm{x}}\right)$ anode. These authors consider that the process is initiated by the water discharge giving the $\mathrm{MO}_{\mathrm{x}}\left({ }^{\circ} \mathrm{OH}\right)$ species physisorbed at the anode surface from the following reaction:

$$
\mathrm{MO}_{\mathrm{x}}+\mathrm{H}_{2} \mathrm{O} \rightarrow \mathrm{MO}_{\mathrm{x}}(\mathrm{OH})+\mathrm{H}^{+}+\mathrm{e}^{-}
$$

and subsequently, the physisorbed species is oxidized to the chemisorbed one $\left(\mathrm{MO}_{\mathrm{x}+1}\right)$ as follows:

$$
\mathrm{MO}_{\mathrm{x}}\left({ }^{\circ} \mathrm{OH}\right) \rightarrow \mathrm{MO}_{\mathrm{x}+1}+\mathrm{H}^{+}+\mathrm{e}^{-}
$$

Both physisorbed and chemisorbed species lead to $\mathrm{O}_{2}$ evolution in the absence of organics. However, when a pollutant $\mathrm{R}$ is present in the solution, the physisorbed species leads to their total mineralization (electrochemical combustion) by the generic reaction:

$$
\left.\mathrm{R}+\mathrm{z} \mathrm{MO}{ }_{\mathrm{x}}{ }^{\circ} \mathrm{OH}\right) \rightarrow \mathrm{CO}_{2}+\mathrm{H}_{2} \mathrm{O}+\mathrm{zMO}_{\mathrm{x}}+\mathrm{zH}^{+}+\mathrm{ze}^{-}
$$

whereas the chemisorbed species gives rise to the formation of partially oxidized products (electrochemical conversion) as follows:

$$
\mathrm{R}+\mathrm{MO}_{\mathrm{x}+1} \rightarrow \mathrm{RO}+\mathrm{MO}_{\mathrm{x}}
$$

In the case of the BDD anode the formation of physisorbed species and its reaction with organics until total combustion are favored.

Indirect electrolysis

More potent indirect electrooxidation methods involving $\mathrm{H}_{2} \mathrm{O}_{2}$ electrogeneration such as electro-Fenton and photoelectron-Fenton are also being developed to destroy toxic aromatic pollutants in acidic wastewaters. These latter methods and anodic oxidation with BDD, so-called electrochemical advanced oxidation processes (EAOPs), are environmentally friendly technologies. In the above indirect electrooxidation methods hydrogen peroxide is continuously generated in the contaminated solution from the two-electron reduction of oxygen at graphite [34], reticulated vitreous carbon [35,36], carbon-felt [37-39] and $\mathrm{O}_{2}$-diffusion [40-45] cathodes:

$$
\mathrm{O}_{2}+2 \mathrm{H}^{+}+2 \mathrm{e}^{-} \rightarrow \mathrm{H}_{2} \mathrm{O}_{2}
$$


When a one-compartment cell is utilized, pollutants can be oxidized by electrogenerated $\mathrm{H}_{2} \mathrm{O}_{2},{ }^{\circ} \mathrm{OH}$ formed at the anode surface from reaction (3) and the weaker oxidant hydroperoxyl radical $\left(\mathrm{HO}_{2}{ }^{\circ}\right)$ produced during the anodic decomposition of $\mathrm{H}_{2} \mathrm{O}_{2}$ :

$$
\begin{gathered}
\mathrm{H}_{2} \mathrm{O}_{2} \rightarrow \mathrm{HO}_{2}^{\cdot}+\mathrm{H}^{+}+\mathrm{e}^{-} \\
\mathrm{HO}_{2}^{\cdot} \rightarrow \mathrm{O}_{2}+\mathrm{H}^{+}+\mathrm{e}^{-}
\end{gathered}
$$

This procedure is known as anodic oxidation with $\mathrm{H}_{2} \mathrm{O}_{2}$ electrogeneration. The electro-Fenton process involves the enhancement of the oxidizing power of the above electrolytic system by adding small amounts of a catalyst like $\mathrm{Fe}^{2+}$, which reacts with electrogenerated $\mathrm{H}_{2} \mathrm{O}_{2}$ to yield ${ }^{\circ} \mathrm{OH}$ in solution from Fenton's reaction (1). The most popular electro-Fenton method is the so-called electrogenerated Fenton's reagent (EFR) [34,37-39], where $\mathrm{O}_{2}$ is bubbled through the solution to be reduced to $\mathrm{H}_{2} \mathrm{O}_{2}$ at the cathode surface. In our laboratory, another electroFenton process has been developed using a one-compartment electrolytic cell with a $\mathrm{Pt}$ or $\mathrm{BDD}$ anode, a carbon-polytetrafluoroethylene (PTFE) $\mathrm{O}_{2}$-fed cathode $\left(\mathrm{O}_{2}\right.$-diffusion cathode $)$ and an acidic contaminated solution containing a small amount of $\mathrm{Fe}^{2+}$ as catalyst [40-45]. Under these conditions, organic pollutants are mainly destroyed by the combined action of ${ }^{\circ} \mathrm{OH}$ generated at the anode from reaction (3) and in the medium from Fenton's reaction (1). The $\mathrm{O}_{2}$ diffusion cathode allows a rapid accumulation of $\mathrm{H}_{2} \mathrm{O}_{2}$ in solution, which quickly produces ${ }^{\circ} \mathrm{OH}$ radicals through reaction (1), the $\mathrm{Fe}^{2+}$ ion being continuously regenerated from the reduction of $\mathrm{Fe}^{3+}$ species: (i) at the cathode, (ii) with $\mathrm{H}_{2} \mathrm{O}_{2}$, (iii) with $\mathrm{HO}_{2}{ }^{\circ}$ and (iv) with intermediate organic radicals.

In the photoelectro-Fenton process the degraded solution is also irradiated with UVA light to enhance the regeneration of $\mathrm{Fe}^{2+}$ through reaction (2). In addition, the mineralization process can be accelerated by the photodecomposition of $\mathrm{Fe}^{3+}$ complexes with some acids, thus allowing regenerating more $\mathrm{Fe}^{2+}[19]$ :

$$
\mathrm{Fe}(\mathrm{OOCR})^{2+}+h v \rightarrow \mathrm{Fe}^{2+}+\mathrm{CO}_{2}+\mathrm{R}^{\cdot}
$$

In the present work we report the possible application of several AOPs and EAOPs to the mineralization of aromatic drugs such as paracetamol, ibuprofen, clofibric acid and salicylic acid in waters. Ozonation processes catalyzed with $\mathrm{Fe}^{2+}, \mathrm{Cu}^{2+}$ and/or UVA light have been chosen as AOPs, whereas electro-Fenton and photoelectro-Fenton using the same catalysts, as well as anodic oxidation with BDD in the absence of catalyst, have been used as EAOPs.

\section{Experimental \\ Chemicals}

Paracetamol, ibuprofen, hydroquinone, $p$-benzoquinone and clofibric, salicylic, tartronic, maleic, fumaric, formic, 2-hydroxybutyric, pyruvic, ketomalonic, 
oxamic and oxalic acids were reagent grade or analytical grade purchased from Sigma-Aldrich, Merck, Panreac and Avocado. Anhydrous sodium sulfate, used as background electrolyte, and heptahydrated ferrous sulfate and pentahydrated cupric sulfate, both used as catalysts, were analytical grade from Fluka. All solutions were prepared with high-purity water obtained from a Millipore Milli-Q system with resistivity $>18 \mathrm{M} \Omega \mathrm{cm}$ at $25{ }^{\circ} \mathrm{C}$. The initial $\mathrm{pH}$ solution was adjusted with $\mathrm{NaOH}$ or sulfuric acid, both of analytical grade from Merck or Fluka, respectively. Organic solvents and other chemicals employed were HPLC or analytical grade from Merck and Fluka.

\section{Degradation systems}

The scheme of the reactor of $100 \mathrm{~mL}$ capacity used for ozonation experiments has been reported previously [17]. All electrolyses were carried out with a thermostated one-compartment conic cell also of $100 \mathrm{~mL}$ capacity. The anode was a Pt sheet of $99.99 \%$ purity from SEMP or a BDD thin-film deposited on a conductive single crystal p-type Si (100) wafers from CSEM, both of $3 \mathrm{~cm}^{2}$ area. The cathode was a stainless steel sheet (AISI 304), a graphite bar or an $\mathrm{O}_{2-}$ diffusion cathode, all of them of $3 \mathrm{~cm}^{2}$ area. The latter cathode, prepared as described elsewhere [42], was fed with pure $\mathrm{O}_{2}$ at $12 \mathrm{~mL} \min ^{-1}$ for $\mathrm{H}_{2} \mathrm{O}_{2}$ electrogeneration from reaction (8). In these electrolytic systems, solutions with a drug content equivalent to $100 \mathrm{mg} \mathrm{L}^{-1}$ of TOC and $0.05 \mathrm{M} \mathrm{Na}_{2} \mathrm{SO}_{4}$ as background electrolyte were comparatively degraded either in acidic medium or in the $\mathrm{pH}$ range 2.0-12.0 at a constant current density of $100 \mathrm{~mA} \mathrm{~cm}$ and $35.0{ }^{\circ} \mathrm{C}$. For the trials with UVA irradiation, a Philips $6 \mathrm{~W}$ fluorescent black light blue tube was placed at the top of the open cell, at $7 \mathrm{~cm}$ above the solution. The tube emitted UVA light in the wavelength region between 300 and $420 \mathrm{~nm}$, with $\lambda_{\max }=360$ $\mathrm{nm}$.

\section{Instruments and equipment}

Ozone was generated with an Erwin Sander 300.5 ozonizer fed with pure $\mathrm{O}_{2}$ at 1.1 bars and at a flow rate of $601 \mathrm{~h}^{-1}$. Electrolyses were carried out with an Amel 2053 potentiostat-galvanostat. The solution $\mathrm{pH}$ was measured with a Crison 2000 $\mathrm{pH}$-meter. Before analysis, samples of treated solutions were filtered with 0.45 $\mu \mathrm{m}$ PTFE filters from Whatman. The degradation of drug solutions was monitored from the reduction of their total organic carbon (TOC), determined on a Shimadzu VCSN TOC analyzer using the standard non-purgeable organic carbon method. The drug decays and the evolution of aromatic intermediates were followed by reversed-phase HPLC chromatography using a Waters 600 high-performance liquid chromatograph fitted with a Spherisorb ODS2 $5 \mu \mathrm{m}, 15$ $\mathrm{cm} \times 4.6 \mathrm{~mm}$ column at room temperature, and connected to a Waters 996 Photodiode Array detector controlled by a Millenium $32^{\circledR}$ program. For each compound, the detector was selected to the maximum wavelength of its UV absorption spectrum. The mobile phase employed in the case of paracetamol was either a 70:30 (v/v) acetonitrile/water or 95:5 (v/v) 0.1 M HCOOH $+\mathrm{NaOH}(\mathrm{pH}$ 3.0)/acetonitrile mixture at $1.2 \mathrm{~mL} \mathrm{~min}^{-1}$, whereas in the case of clofibric acid it 
was a 50:47:3 (v/v/v) methanol/0.01 M phosphate buffer $(\mathrm{pH}=2.5) /$ pentanol

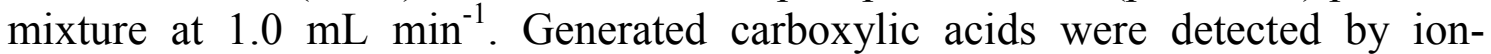
exclusion chromatography using the above liquid chromatograph fitted with a Bio-Rad Aminex HPX 87H, $30 \mathrm{~cm} \times 7.8 \mathrm{~mm}$, column at $35^{\circ} \mathrm{C}$ and selecting the photodiode detector at $\lambda=210 \mathrm{~nm}$. In these trials a $4 \mathrm{mM} \mathrm{H}_{2} \mathrm{SO}_{4}$ solution at 0.6 $\mathrm{mL} \mathrm{min}^{-1}$ was employed as mobile phase. $\mathrm{Cl}^{-}$and $\mathrm{NO}_{3}{ }^{-}$concentrations in treated solutions were obtained by ion chromatography using a Shimadzu 10Avp HPLC chromatograph fitted with a Shim-Pack IC-A1S, $10 \mathrm{~cm} \times 4.6 \mathrm{~mm}$, anion column at $40{ }^{\circ} \mathrm{C}$ and coupled with a Shimadzu CDD 10Avp conductivity detector. These measurements were made under circulation of an aqueous mobile phase

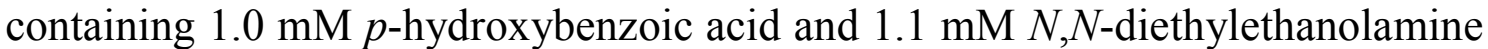
at $1.5 \mathrm{~mL} \mathrm{~min}{ }^{-1}$. $\mathrm{NH}_{4}^{+}$concentration in degraded paracetamol solutions was determined from the standard colorimetric method with Nessler's reagent, using a Unicam UV/Vis UV4 Prisma double-beam spectrometer thermostated at $25{ }^{\circ} \mathrm{C}$. The $\mathrm{H}_{2} \mathrm{O}_{2}$ content in ozonated solutions was obtained from the light absorption of the titanic-hydrogen peroxide colored complex at $\lambda=408 \mathrm{~nm}$, determined with the above spectrometer.

\section{Results and discussion \\ AOPs}

Direct and catalyzed ozonation

The degradation of paracetamol and ibuprofen was studied by direct ozonation and ozonation catalyzed with $\mathrm{Fe}^{2+}, \mathrm{Cu}^{2+}$ and/or UVA light in acid medium to compare the oxidizing power of the different systems. Fig. 1 shows the TOC decay with time for a $157 \mathrm{mg} \mathrm{L}^{-1}$ paracetamol solution of $\mathrm{pH} 3.0$ and a $146 \mathrm{mg}$ $\mathrm{L}^{-1}$ ibuprofen solution of $\mathrm{pH} 6.0$ at $25{ }^{\circ} \mathrm{C}$. As can be seen, more than $83 \%$ of mineralization is attained when solutions are treated by ozonation catalyzed with $\mathrm{Fe}^{2+}, \mathrm{Cu}^{2+}$ and/or UVA light. The initial mineralization rate in the $\mathrm{O}_{3}$ (curves $a$ and $g$ ) and $\mathrm{O}_{3} / \mathrm{UVA}$ (curves $d$ and $h$ ) methods is similar, but the degradation rate at long time is strongly accelerated in the $\mathrm{O}_{3} / \mathrm{UVA}$ system, reducing the TOC of both drug solutions by $96 \%$ in $4 \mathrm{~h}$. Under these conditions, $\mathrm{H}_{2} \mathrm{O}_{2}$ is expected to be formed as secondary product of $\mathrm{O}_{3}$ reaction with olefinic products coming from the breaking of the aromatic moiety of the drugs [46]. The evolution of $\mathrm{H}_{2} \mathrm{O}_{2}$ concentration during these trials is depicted in Fig. 2. A steady concentration of this weak oxidant, close to $0.20 \mathrm{mM}$, can be observed in direct ozonation, indicating that pollutants are mainly degraded by ozone leading to a low mineralization due to the great stability of final carboxylic acids. In the $\mathrm{O}_{3}$ /UVA system, $\mathrm{H}_{2} \mathrm{O}_{2}$ is quickly accumulated in the medium to reach a maximum concentration of about $1 \mathrm{mM}$ in $5 \mathrm{~min}$ by the additional photolysis of ozone [13]:

$$
\mathrm{O}_{3}+\mathrm{H}_{2} \mathrm{O}+h \mathrm{v} \rightarrow \mathrm{H}_{2} \mathrm{O}_{2}+\mathrm{O}_{2}
$$




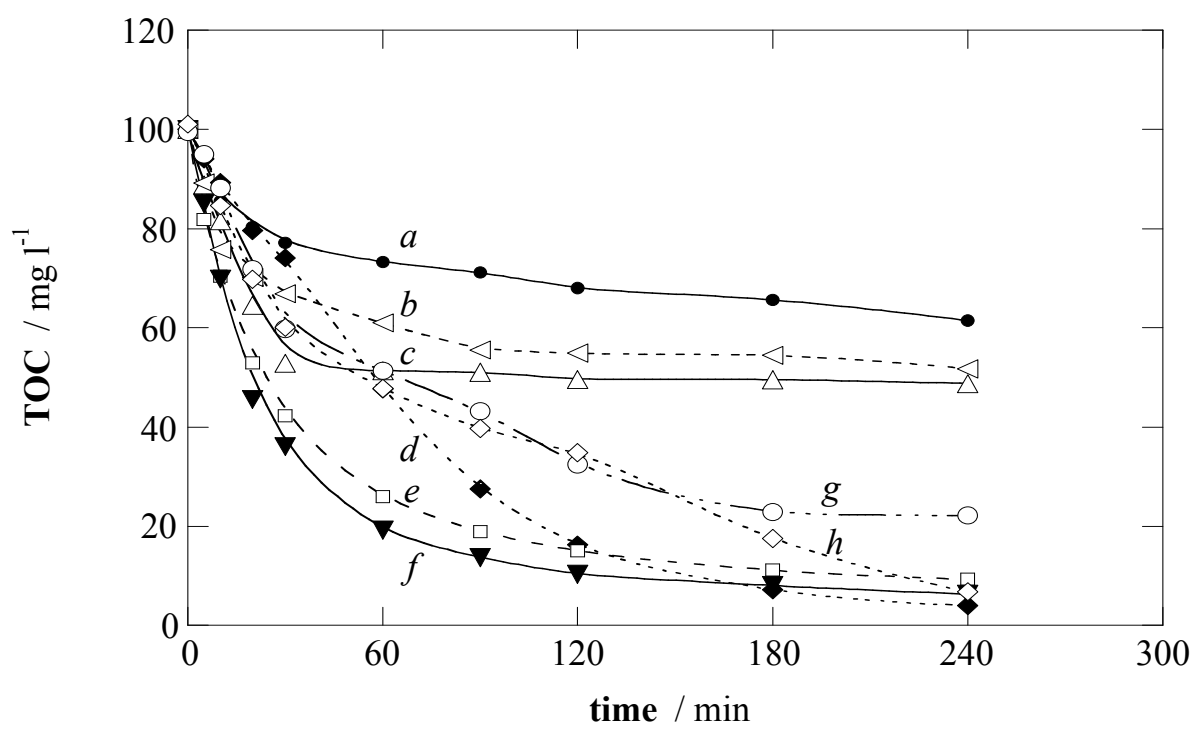

Figure 1. TOC removal with time during the mineralization of $100 \mathrm{~mL}$ of solutions containing $(a, b, c, d, e, f) 157 \mathrm{mg} \mathrm{L}^{-1}$ paracetamol or $(g, h) 146 \mathrm{mg} \mathrm{L}^{-1}$ ibuprofen of $\mathrm{pH} 3.0$ by the system: $(a, \bullet)$ and $\left(g, \mathrm{O}_{3},(b, \triangleleft) \mathrm{O}_{3}+0.25 \mathrm{mM} \mathrm{Cu}^{2+},(c, \Delta) \mathrm{O}_{3}+1.0 \mathrm{mM} \mathrm{Fe}^{2+}\right.$, $(d, \diamond)$ and $(h, \diamond) \mathrm{O}_{3} / \mathrm{UVA},(e, \square) \mathrm{O}_{3}+1.0 \mathrm{mM} \mathrm{Fe}^{2+}+\mathrm{UVA}$ and $(f, \boldsymbol{\nabla}) \mathrm{O}_{3}+1.0 \mathrm{mM} \mathrm{Fe}^{2+}$ $+0.25 \mathrm{mM} \mathrm{Cu}^{2+}+\mathrm{UVA}$. Ozone flow rate $1.0 \mathrm{~g} \mathrm{~h}^{-1}$. Temperature $25.0^{\circ} \mathrm{C}$.

However, this species is further slowly removed to disappear in $30 \mathrm{~min}$. The overall mineralization attained with this system can then be ascribed to the induction of UVA light to the direct photolysis of organics or their activation to be destroyed by $\mathrm{O}_{3}$ and/or $\mathrm{H}_{2} \mathrm{O}_{2}$ generated by reaction (12).

When $\mathrm{Fe}^{2+}$ is added to the solution, $\mathrm{H}_{2} \mathrm{O}_{2}$ is rapidly consumed by Fenton's reaction (1) producing ${ }^{\circ} \mathrm{OH}$ (see Fig. 2), although this radical can also be formed from reaction of $\mathrm{Fe}^{2+}$ with ozone $[17,18]$ :

$$
\begin{gathered}
\mathrm{Fe}^{2+}+\mathrm{O}_{3} \rightarrow \mathrm{FeO}^{2+}+\mathrm{O}_{2} \\
\mathrm{FeO}^{2+}+\mathrm{H}_{2} \mathrm{O} \rightarrow \mathrm{Fe}^{3+}+{ }^{\circ} \mathrm{OH}+\mathrm{OH}^{-}
\end{gathered}
$$

This explains the high degradation rate found during the early stages of the $\mathrm{O}_{3} / \mathrm{Fe}^{2+}$ system (see curve $c$ of Fig. 1), whereas at long times the solution TOC drops slowly by the formation of carboxylic acids that are hardly destroyed.

The degradation process is much faster using $\mathrm{O}_{3} / \mathrm{Fe}^{2+} / \mathrm{UVA}$ (see curve $e$ of Fig. 1) by the additional production of ${ }^{\circ} \mathrm{OH}$ from reactions (1) and (2). The highest oxidizing power is achieved with the $\mathrm{O}_{3} / \mathrm{Fe}^{2+}+\mathrm{Cu}^{2+} / \mathrm{UVA}$ system (see curve $f$ of Fig.1), since more ${ }^{\circ} \mathrm{OH}$ can be produced from the Fenton-like reaction between $\mathrm{H}_{2} \mathrm{O}_{2}$ and the $\mathrm{Cu}^{2+} / \mathrm{Cu}^{+}$couple, along with a more rapid oxidation of some $\mathrm{Cu}^{2+}$ complexes than the corresponding $\mathrm{Fe}^{3+}$ ones [17]. 


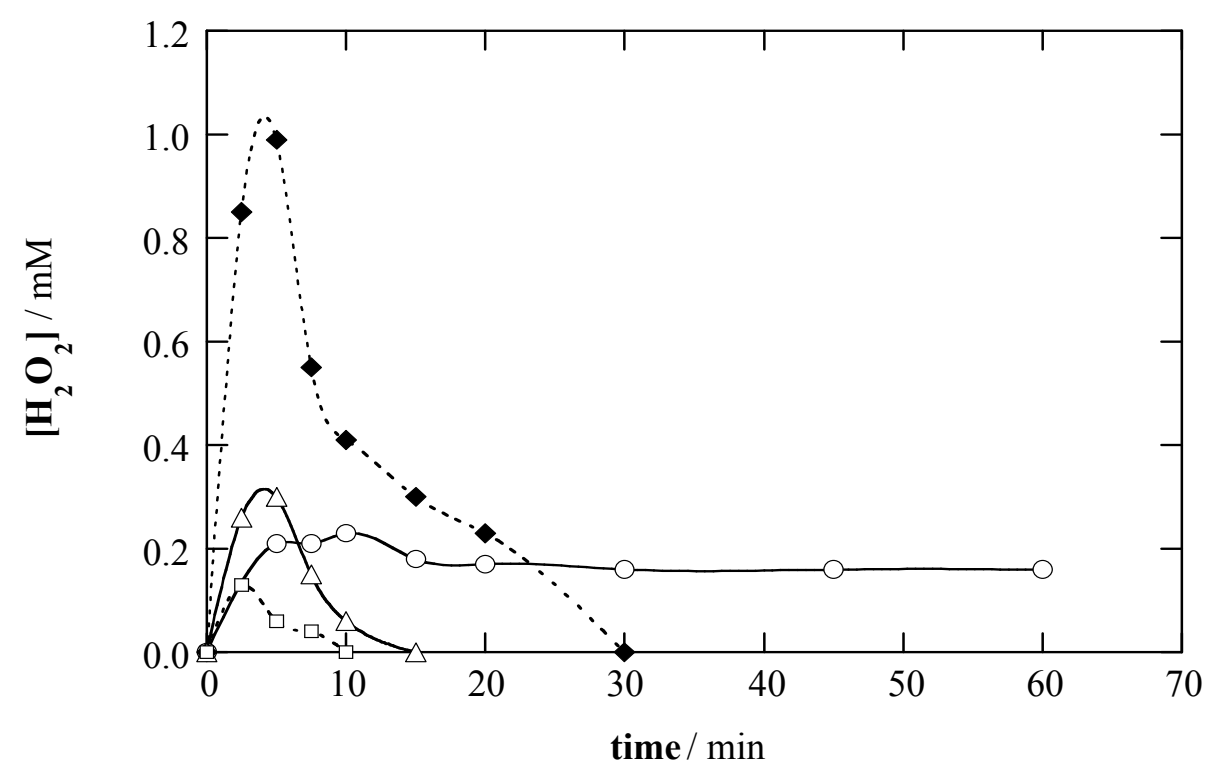

Figure 2. Evolution of $\mathrm{H}_{2} \mathrm{O}_{2}$ concentration with time during the mineralization of 100 $\mathrm{mL}$ of a $157 \mathrm{mg} \mathrm{L}^{-1}$ paracetamol solution of $\mathrm{pH} 3.0$ by the system: (O) $\mathrm{O}_{3}$, $\mathrm{O}_{3} / \mathrm{UVA},(\Delta) \mathrm{O}_{3}+1.0 \mathrm{mM} \mathrm{Fe}^{2+}$ and $(\square) \mathrm{O}_{3}+1.0 \mathrm{mM} \mathrm{Fe}^{2+}+$ UVA. Ozone flow rate 1.0 $\mathrm{g} \mathrm{h}^{-1}$. Temperature $25.0^{\circ} \mathrm{C}$.

The increase in ${ }^{\circ} \mathrm{OH}$ concentration in the above $\mathrm{Fe}^{2+}$ catalyzed ozonation systems was verified from the degradation of a $0.22 \mathrm{mM}$ oxamic acid solution of $\mathrm{pH} 3.0$ in the presence and absence of $30 \mathrm{mM} t$-butanol as scavenger of hydroxyl radicals. The oxamic concentration decay was followed by ion-exclusion chromatography. Fig. 3 shows that all ozonation processes catalyzed with $\mathrm{Fe}^{2+}$, $\mathrm{Cu}^{2+}$ and/or UVA light yield a more or less rapid destruction of oxamic acid, but the degradation of this acid is strongly inhibited in the presence of $t$-butanol, as expected if ${ }^{\circ} \mathrm{OH}$ is the main oxidizing agent in all cases. Note that oxamic acid is more quickly destroyed by the $\mathrm{O}_{3} / \mathrm{Fe}^{2+} / \mathrm{UVA}$ system than the $\mathrm{O}_{3} / \mathrm{Fe}^{2+}$ one due to the greater ${ }^{\circ} \mathrm{OH}$ production under the action of UVA light on reactions (2) and (12). The fastest degradation of this acid using $\mathrm{O}_{3} / \mathrm{Fe}^{2+}+\mathrm{Cu}^{2+} / \mathrm{UVA}$ (see Fig. 3) can then be ascribed to the quicker destruction of $\mathrm{Cu}^{2+}$-oxamato complexes than $\mathrm{Fe}^{3+}$-oxamato ones with ${ }^{\circ} \mathrm{OH}$. This positive effect of $\mathrm{Cu}^{2+}$ on the degradation of final carboxylic acids could explain the highest oxidizing power of the $\mathrm{O}_{3} / \mathrm{Fe}^{2+}+$ $\mathrm{Cu}^{2+} /$ UVA system (see Fig. 1), as stated above. 


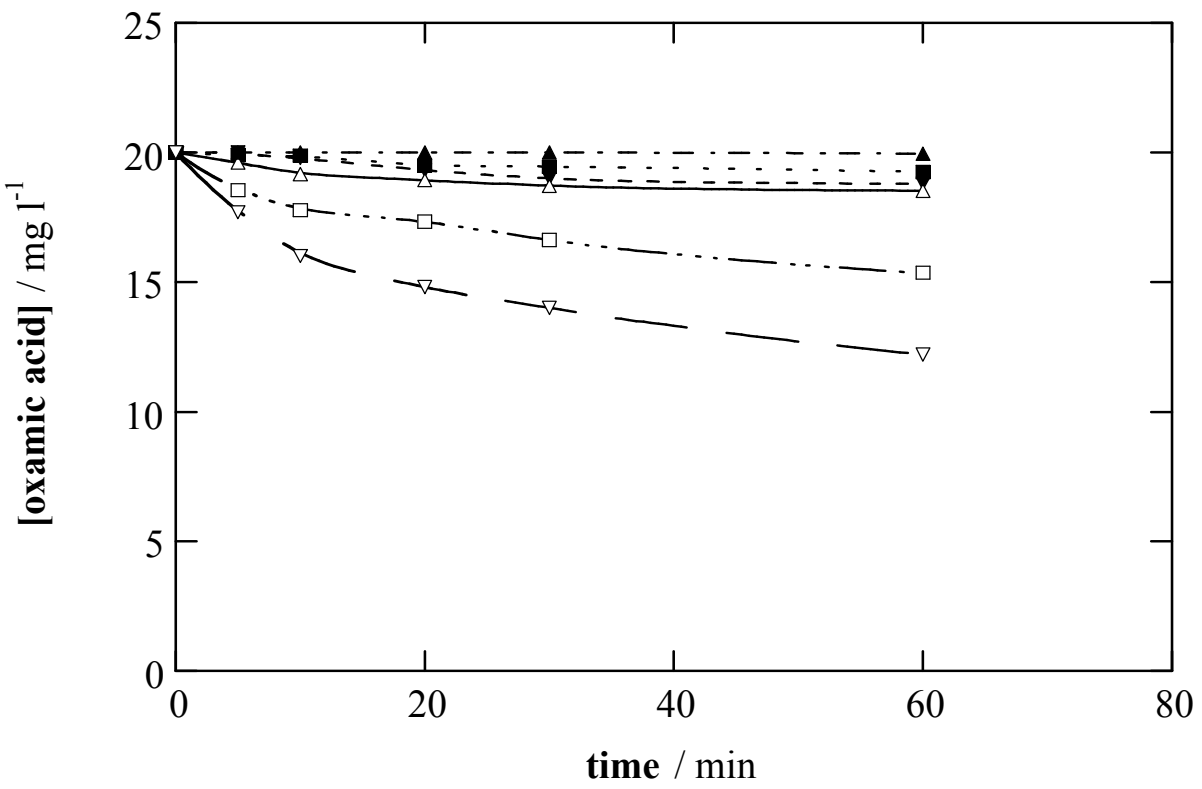

Figure 3. Effect of hydroxyl radicals generated in $\mathrm{Fe}^{2+}$ catalyzed ozonation processes on the degradation of a $20 \mathrm{mg} \mathrm{L}^{-1}(0.22 \mathrm{mM})$ oxamic acid solution of $\mathrm{pH} 3.0$. System: $(\Delta, \boldsymbol{\Delta}) \mathrm{O}_{3}+1.0 \mathrm{mM} \mathrm{Fe}^{2+},(\square, \boldsymbol{\square}) \mathrm{O}_{3}+1.0 \mathrm{mM} \mathrm{Fe}^{2+}+\mathrm{UVA}$ and $(\nabla, \boldsymbol{\nabla}) \mathrm{O}_{3}+1.0 \mathrm{mM}$ $\mathrm{Fe}^{2+}+0.25 \mathrm{mM} \mathrm{Cu}{ }^{2+}+$ UVA. In curves $(\boldsymbol{\Lambda}, \boldsymbol{\nabla}, \boldsymbol{\nabla}) 30 \mathrm{mM} t$-butanol was added to the initial solution. Ozone flow rate $1.0 \mathrm{~g} \mathrm{~h}^{-1}$. Temperature $25.0^{\circ} \mathrm{C}$.

\section{EAOPS}

\section{Anodic oxidation}

This technique was initially tested by treating solutions with $157 \mathrm{mg} \mathrm{L}^{-1}$ paracetamol and $0.05 \mathrm{M} \mathrm{Na}_{2} \mathrm{SO}_{4}$ using a $\mathrm{Pt}$ or BDD anode and a graphite cathode. Fig. 4 shows the TOC vs. specific charge $\left(Q\right.$, in $\left.\mathrm{A} \mathrm{h} \mathrm{L}^{-1}\right)$ plots obtained for these trials in the $\mathrm{pH}$ range $2.0-12.0$ at $100 \mathrm{~mA} \mathrm{~cm}$. In the experiments performed with $\mathrm{pH}$ between 3.0 and 10.0, the solution $\mathrm{pH}$ underwent a progressive decay with time due to the formation of acid intermediates and for this reason it was continuously regulated to its initial $\mathrm{pH}$ value with $0.1 \mathrm{M}$ $\mathrm{NaOH}$. A quite slow mineralization can be seen in Fig. 4 using a Pt anode, although the degradation rate raises with increasing $\mathrm{pH}$ to attain a maximum TOC decay close to $35 \%$ after $6 \mathrm{~h}$ of electrolysis at $\mathrm{pH} 10.0$ and $12.0(Q=18 \mathrm{~A} \mathrm{~h}$ $\left.1^{-1}\right)$. The higher mineralization of paracetamol in alkaline medium can be due to the generation of a greater ${ }^{\circ} \mathrm{OH}$ concentration at the Pt surface from reaction (15)

$$
\mathrm{OH}^{-} \rightarrow{ }^{\circ} \mathrm{OH}_{(\mathrm{ads})}+\mathrm{e}^{-}
$$

than from reaction (3), and/or the faster destruction of more easily oxidizable products present in alkaline medium, as anionic forms of possible phenolic derivatives [25]. 


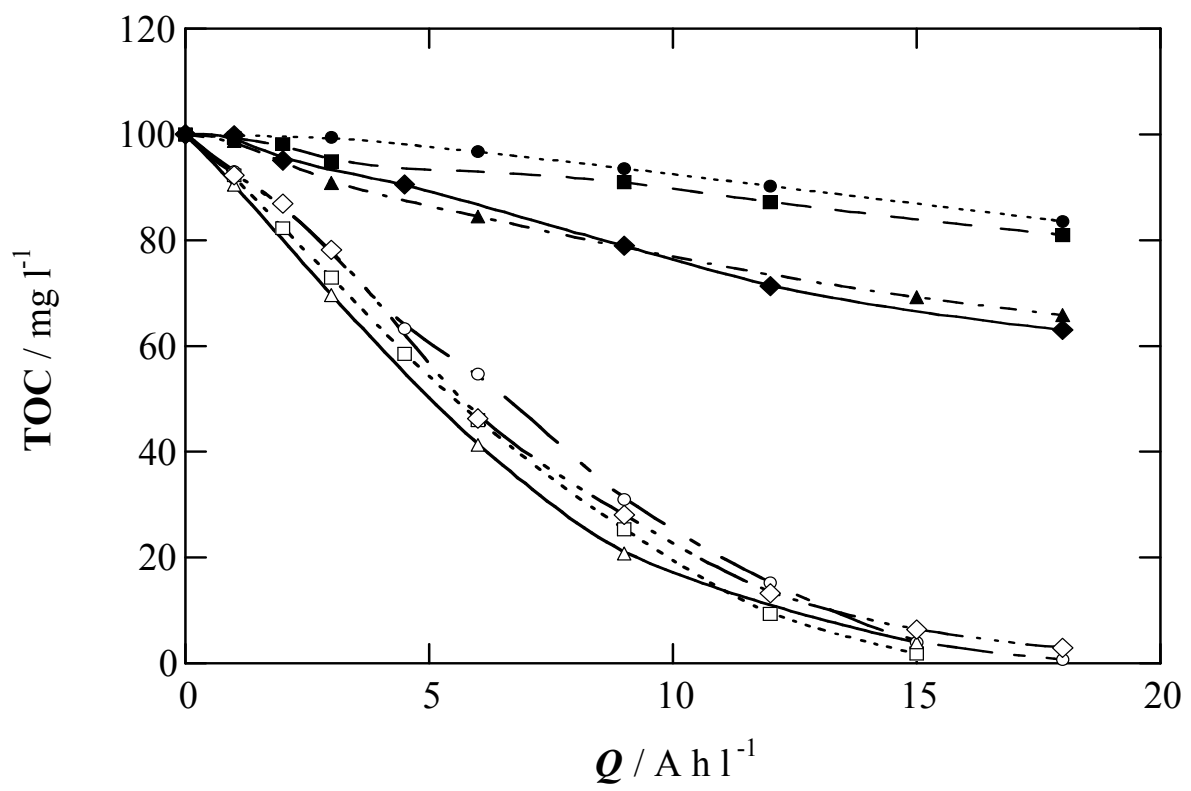

Figure 4. Dependence of TOC decay on specific charge for the anodic oxidation of 100 $\mathrm{mL}$ of a $157 \mathrm{mg} \mathrm{L}^{-1}$ paracetamol solution in $0.05 \mathrm{M} \mathrm{Na}_{2} \mathrm{SO}_{4}$ at $100 \mathrm{~mA} \mathrm{~cm}{ }^{-2}$ and at 35.0 ${ }^{\circ} \mathrm{C}$ using a one-compartment cell with a $(\boldsymbol{\bullet}, \mathbf{\square}, \boldsymbol{\Lambda}, \diamond)$ Pt or $(O, \square, \Delta, \diamond)$ BDD anode and a graphite cathode, all of them of $3 \mathrm{~cm}^{2}$ area. Initial $\mathrm{pH}:(\bullet, \bigcirc) 2.0,(\boldsymbol{\square}, \square) 3.0,(\boldsymbol{\Delta}, \Delta)$ 10.0 and $(\diamond, \diamond) 12.0$.

Fig. 4 shows a different behavior when a BDD anode is used, since TOC drops in a similar way in all media tested, reaching overall mineralization at $Q$ values between 15 and $18 \mathrm{~A} \mathrm{~h} \mathrm{~L}^{-1}$. This may be related to the fact that the amount of $\mathrm{OH}$ at the BDD surface is always so high that all oxidation products are degraded at similar rate in the $\mathrm{pH}$ range 2.0-12.0 tested.

The same trends were also found for $179 \mathrm{mg} \mathrm{L}^{-1}$ clofibric acid solutions degraded under comparable conditions, but using a stainless steel cathode. Fig. 5 shows that the use of a $\mathrm{Pt}$ anode leads to a slow TOC abatement until a mineralization near $30 \%$ in $4 \mathrm{~h}$, whereas at longer times no further decontamination takes place. All colorless starting solutions changed to pale rose in $5 \mathrm{~min}$ of electrolysis, becoming colorless again after $6 \mathrm{~h}$ of treatment. This coloration can be related to the generation of soluble chloro-polyaromatics that can be completely destroyed by ${ }^{\circ} \mathrm{OH}$ produced from reaction (3) or (15), with loss of chloride ion. Ion chromatography analysis of treated solutions revealed that released $\mathrm{Cl}^{-}$remains stable in solution, being quickly accumulated until a quasisteady concentration of about 29 of $\mathrm{mg} \mathrm{L}^{-1}$, which is practically equal to the initial chlorine content in solution of $29.5 \mathrm{mg} \mathrm{L}^{-1}$. In contrast, when a BDD anode is employed, a continuous and faster TOC removal takes place for all treated solutions (see Fig. 5), attaining more than $91 \%$ of mineralization in $7 \mathrm{~h}(Q=21 \mathrm{~A}$ $\mathrm{h} \mathrm{L}^{-1}$ ). All treated solutions always remained colorless probably due to the faster destruction of aromatic intermediates by the greater amount of ${ }^{\circ} \mathrm{OH}$ formed at the $\mathrm{BDD}$ surface. Released $\mathrm{Cl}^{-}$in these trials was removed from the solution since it is slowly oxidized to chlorine at the BDD anode. 


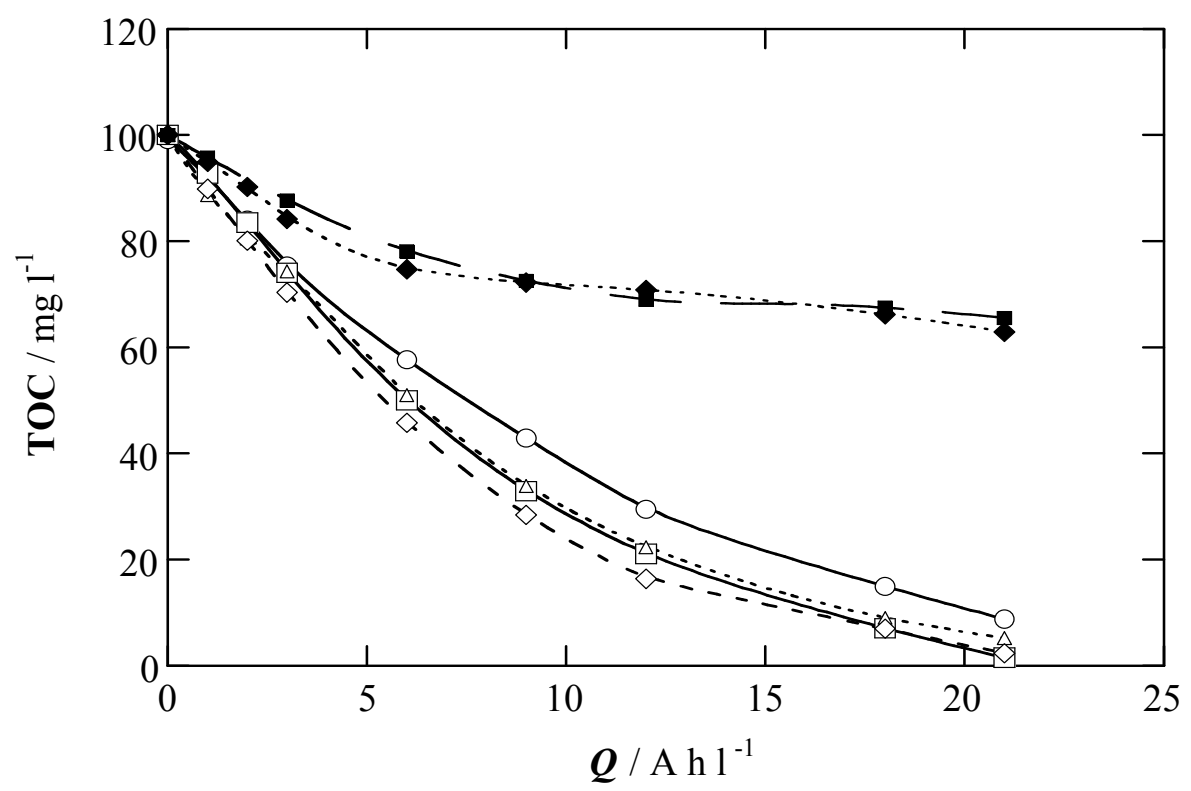

Figure 5. TOC abatement versus specific charge for the anodic oxidation of $100 \mathrm{~mL}$ of $179 \mathrm{mg} \mathrm{L}^{-1}$ clofibric acid solutions in $0.05 \mathrm{M} \mathrm{Na}_{2} \mathrm{SO}_{4}$ at $100 \mathrm{~mA} \mathrm{~cm}{ }^{-2}$ and at $35.0{ }^{\circ} \mathrm{C}$ using a one-compartment cell with a $(\mathbf{\square}, \diamond)$ Pt or $(O, \square, \Delta, \diamond)$ BDD anode and a stainless steel cathode, all of them of $3 \mathrm{~cm}^{2}$ area. Initial pH: $(O) 2.0,(\boldsymbol{\square}, \square) 3.0,(\Delta)$ 10.0 and $(\diamond, \diamond) 12.0$.

The clofibric acid concentration decay with electrolysis time was followed by reversed-phase chromatography. The kinetic results obtained in several experimental conditions using a Pt and BDD anode are given in Figs. 6a and 6b, respectively. These data show that the reaction between this drug and ${ }^{\circ} \mathrm{OH}$ at the anode surface always fit to a pseudo-first order kinetic equation. This reaction is $\mathrm{pH}$-independent, thus confirming the formation of a similar amount of reactive $\mathrm{OH}$ in acidic and alkaline media from reactions (3) and (15), respectively. The clofibric acid decay becomes faster with increasing current density from 33 to $100 \mathrm{~mA} \mathrm{~cm}^{-2}$ due to the formation of more ${ }^{\circ} \mathrm{OH}$. A quicker decay of this drug using Pt instead BDD can also be deduced by comparing Figs. 6a and 6b, suggesting a greater adsorption of clofibric acid on the Pt surface that accelerates its reaction with ${ }^{\circ} \mathrm{OH}$. Comparison of Figs. 5 and $6 \mathrm{~b}$ allows concluding that the time required for clofibric acid disappearance using BDD agrees with the time needed for its total mineralization, as expected if it is oxidized in parallel to its products. 

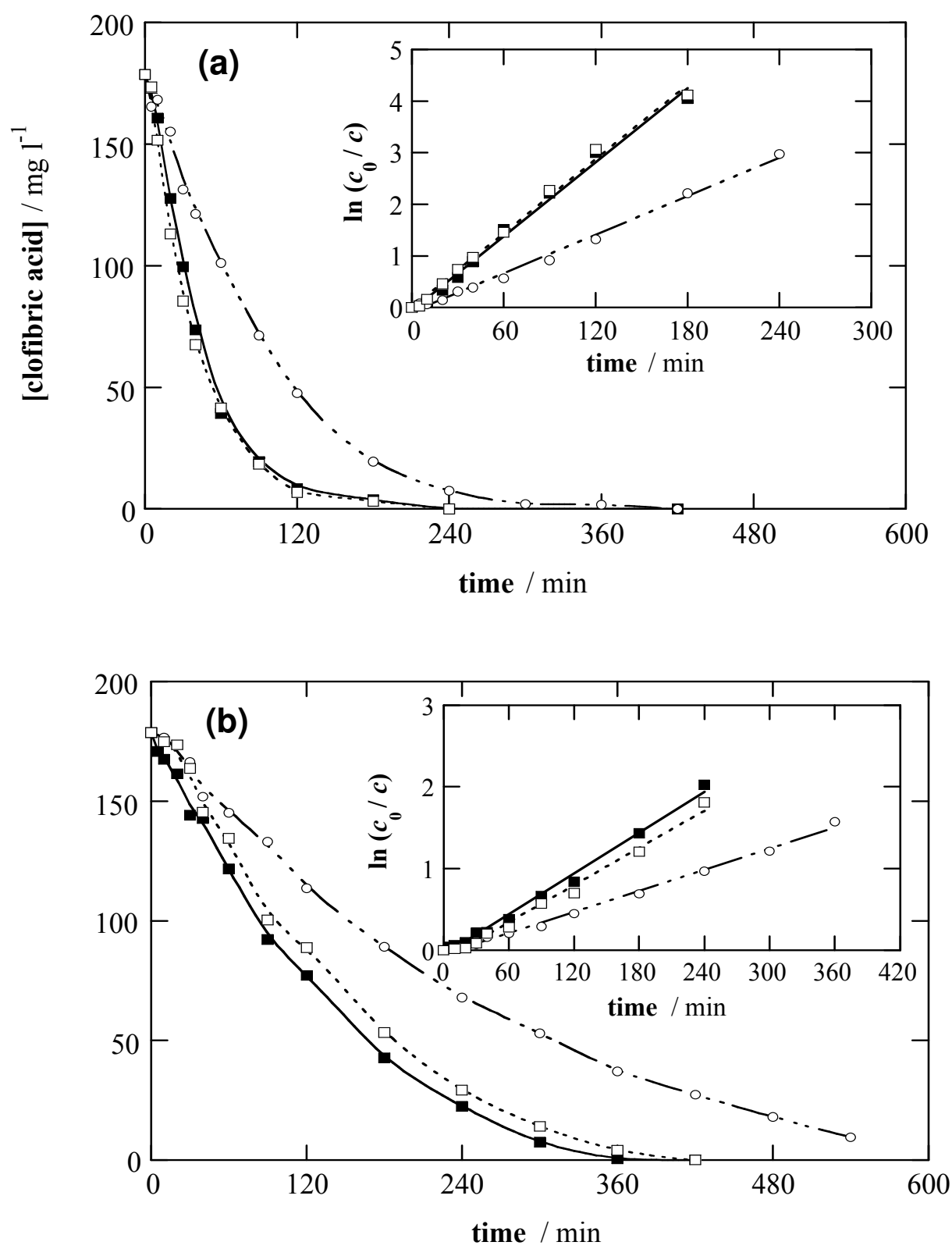

Figure 6. Clofibric acid concentration decay with electrolysis time for the treatment of $100 \mathrm{~mL}$ of $179 \mathrm{mg} \mathrm{L}^{-1}$ drug solutions at $35.0^{\circ} \mathrm{C}$ by anodic oxidation with a: (a) $\mathrm{Pt}$ and (b) BDD electrode. Initial pH: (ם) 3.0 and $(O, \square)$ 12.0. Current density: (O) $33 \mathrm{~mA}$ $\mathrm{cm}^{-2}$ and $(\boldsymbol{\square}, \square) 100 \mathrm{~mA} \mathrm{~cm}$. Each inset panel presents the corresponding kinetic analysis assuming a pseudo-first-order reaction for clofibric acid.

Carboxylic acids such as tartronic, maleic, fumaric, formic, 2-hydroxybutyric, pyruvic and oxalic were identified by ion-exclusion chromatography as generated products during anodic oxidation of clofibric acid. These acids remain stable in solution using $\mathrm{Pt}$, but they are totally converted into $\mathrm{CO}_{2}$ at a BDD anode, then being simultaneously oxidized with the initial drug. 

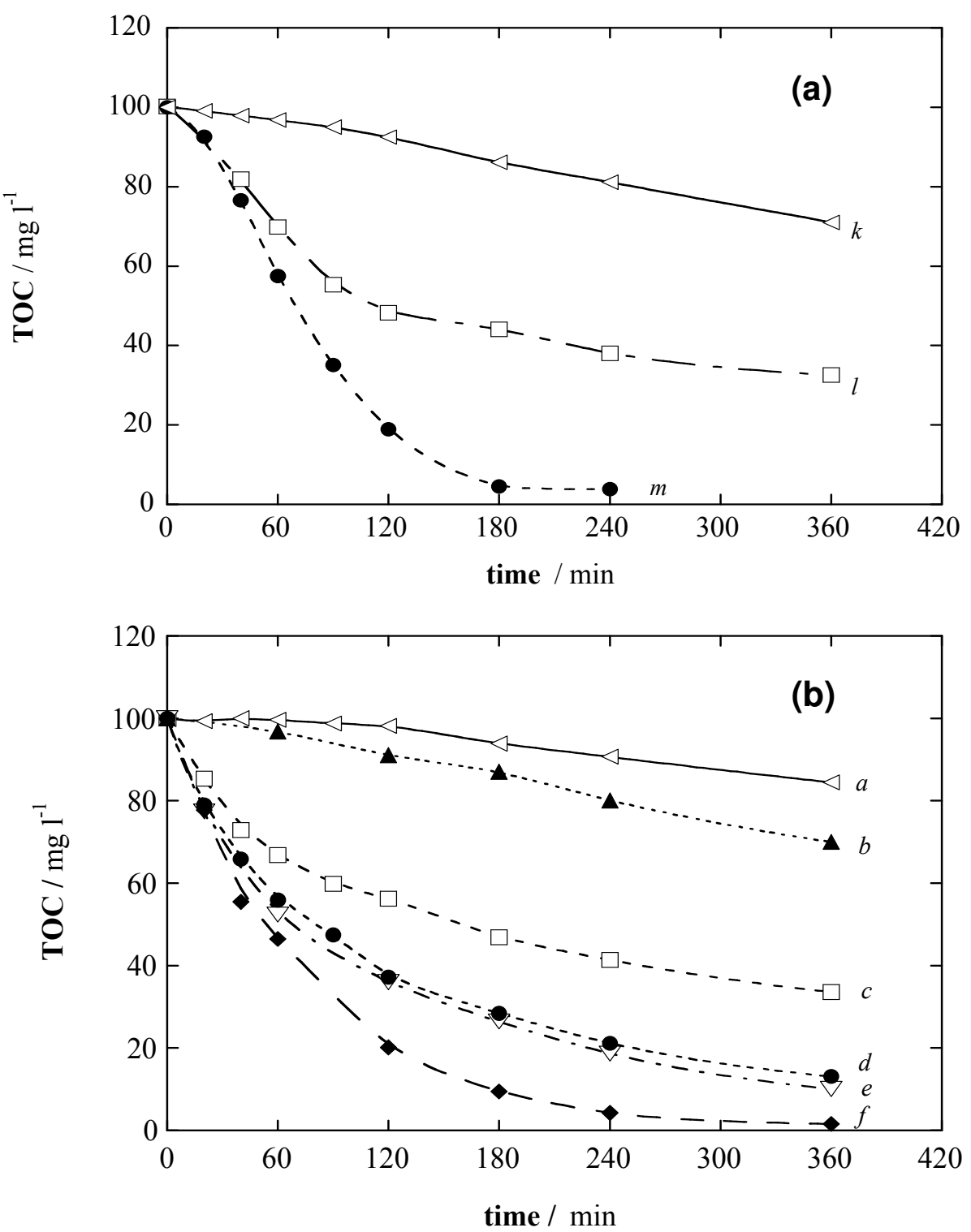

Figure 7. TOC removal with electrolysis time for the degradation of $100 \mathrm{~mL}$ of (a) 164 $\mathrm{mg} \mathrm{L}^{-1}$ salicylic acid and (b) $157 \mathrm{mg} \mathrm{L}^{-1}$ paracetamol solutions in $0.05 \mathrm{M} \mathrm{Na}_{2} \mathrm{SO}_{4}$ of $\mathrm{pH}$ 3.0 at $100 \mathrm{~mA} \mathrm{~cm}^{-2}$ and at $35.0{ }^{\circ} \mathrm{C}$ using a one-compartment cell with a $3 \mathrm{~cm}^{2} \mathrm{Pt}$ anode and a $3 \mathrm{~cm}^{2} \mathrm{O}_{2}$-diffusion cathode for $\mathrm{H}_{2} \mathrm{O}_{2}$ electrogeneration. Catalyst: $(a, \triangleleft)$ and $(k, \triangleleft)$ None (anodic oxidation with $\mathrm{H}_{2} \mathrm{O}_{2}$ electrogeneration), $(b, \boldsymbol{\Delta}) 1.0 \mathrm{mM} \mathrm{Cu}^{2+}+\mathrm{UVA}$ light, $(c, \square)$ and $(l, \square) 1.0 \mathrm{mM} \mathrm{Fe}^{2+}$ (electro-Fenton process), $(d, \bullet)$ and $(m, \bullet) 1.0 \mathrm{mM} \mathrm{Fe}^{2+}+$ UVA light (photoelectro-Fenton process), $(e, \nabla) 1.0 \mathrm{mM} \mathrm{Fe}^{2+}+1.0 \mathrm{mM} \mathrm{Cu}^{2+}$ and $(f$, $1.0 \mathrm{mM} \mathrm{Fe}^{2+}+1.0 \mathrm{mM} \mathrm{Cu}^{2+}+$ UVA light.

\section{Indirect electrooxidation methods}

To clarify the possible application of indirect electrooxidation methods with $\mathrm{H}_{2} \mathrm{O}_{2}$ electrogeneration to the removal of aromatic drugs from waters, we carried out a study on the mineralization of solutions containing $164 \mathrm{mg} \mathrm{L}^{-1}$ salicylic acid and $157 \mathrm{mg} \mathrm{L}^{-1}$ paracetamol at $\mathrm{pH} 3.0$ using a $\mathrm{Pt}$ anode and an $\mathrm{O}_{2}$-diffusion cathode in the presence and in the absence of $\mathrm{Fe}^{2+}, \mathrm{Cu}^{2+}$ and/or UVA light as catalysts. The corresponding TOC-time plots obtained at $100 \mathrm{~mA} \mathrm{~cm} \mathrm{cor}^{-2}$ for such 
drugs are depicted in Figs. $7 \mathrm{a}$ and $7 \mathrm{~b}$, respectively. Anodic oxidation with $\mathrm{H}_{2} \mathrm{O}_{2}$ electrogeneration leads to a poor decontamination of salicylic acid (see curve $k$ of Fig. 7a), due to the low concentration of ${ }^{\circ} \mathrm{OH}$ formed at the anode surface from reaction (3), which is the main oxidant of the drug and its products. In contrast, the use of $\mathrm{Fe}^{2+}$ catalyst strongly accelerates the degradation rate of this compound due to the additional production of ${ }^{\circ} \mathrm{OH}$ from Fenton's reaction (1). Thus, electroFenton only yields $60 \%$ of decontamination at $6 \mathrm{~h}$ (see curve $l$ of Fig. 7a), whereas complete mineralization can be attained after $4 \mathrm{~h}$ of photoelectro-Fenton. The highest oxidizing power of the latter method can be related to the photodecomposition of $\mathrm{Fe}^{3+}$ complexes with final carboxylic acids by UVA light (reaction (11)).

A similar behavior can be observed in Fig. $7 \mathrm{~b}$ for the degradation of paracetamol. The treatment by anodic oxidation with $\mathrm{H}_{2} \mathrm{O}_{2}$ electrogeneration (see curve $a$ of Fig. $7 \mathrm{~b}$ ) only yields $15 \%$ of mineralization in $6 \mathrm{~h}$, thus corroborating the quite small concentration of ${ }^{\circ} \mathrm{OH}$ adsorbed on Pt produced from reaction (3). The slightly faster degradation observed in curve $b$ of Fig. $7 \mathrm{~b}$ when the solution contains $1.0 \mathrm{mM} \mathrm{Cu}^{2+}$ and is exposed to UVA light can be explained by the production of small amounts of ${ }^{\circ} \mathrm{OH}$ in the medium from the $\mathrm{Cu}^{2+} / \mathrm{Cu}^{+}$catalytic system [47] and the additional photolysis of some oxidation products. For the electro-Fenton process with $1.0 \mathrm{mM} \mathrm{Fe}^{2+}$ as catalyst (see curve $c$ of Fig. $7 \mathrm{~b}$ ), the solution TOC is more quickly removed, as expected from the great amount of 'OH produced in the medium from Fenton's reaction (1), but total mineralization is not possible due to the formation of stable $\mathrm{Fe}^{3+}$ complexes with final carboxylic acids that are not destroyed with ${ }^{\circ} \mathrm{OH}$. Paracetamol mineralization increases up to $87 \%$ when $1.0 \mathrm{mM} \mathrm{Fe}^{2+}$ and UVA light are combined as catalysts in the photoelectro-Fenton process (see curve $d$ of Fig. 7b), due to the efficient photolysis of the above complexes via reaction (11), or when $1.0 \mathrm{mM} \mathrm{Fe}{ }^{2+}$ and $1.0 \mathrm{mM} \mathrm{Cu}{ }^{2+}$ are added to the solution in the electro-Fenton process with $\mathrm{Cu}^{2+}$ (see curve $e$ of Fig. 7b). This suggests the existence of a parallel oxidation of $\mathrm{Cu}^{2+}$ complexes with final carboxylic acids. When all catalysts are combined in the photoelectro-Fenton process with $\mathrm{Cu}^{2+}$ (see curve $f$ of Fig. 7b), all degradation paths take place simultaneously, thus allowing the complete mineralization of paracetamol in $6 \mathrm{~h}$. These results indicate that the oxidation ability of the above EAOPs increases in the order: anodic oxidation with $\mathrm{H}_{2} \mathrm{O}_{2}$ electrogeneration $<1.0 \mathrm{mM} \mathrm{Cu}^{2+}+\mathrm{UVA}$ light $<$ electro-Fenton $<$ photoelectroFenton $\leq$ electro-Fenton with $\mathrm{Cu}^{2+}<$ photoelectro-Fenton with $\mathrm{Cu}^{2+}$.

The paracetamol concentration decay for the above trials, determined by reversed-phase chromatography, is depicted in Fig. 8. This compound undergoes a slow and similar decay in the processes without $\mathrm{Fe}^{2+}$ catalyst, disappearing from the medium after 75 min of electrolysis. In contrast, it is quickly removed in 6 min for all treatments with $\mathrm{Fe}^{2+}$. This confirms that the amount of ${ }^{\circ} \mathrm{OH}$ generated in the medium from Fenton's reaction (1) is much higher that that produced at the Pt surface from reaction (3). 


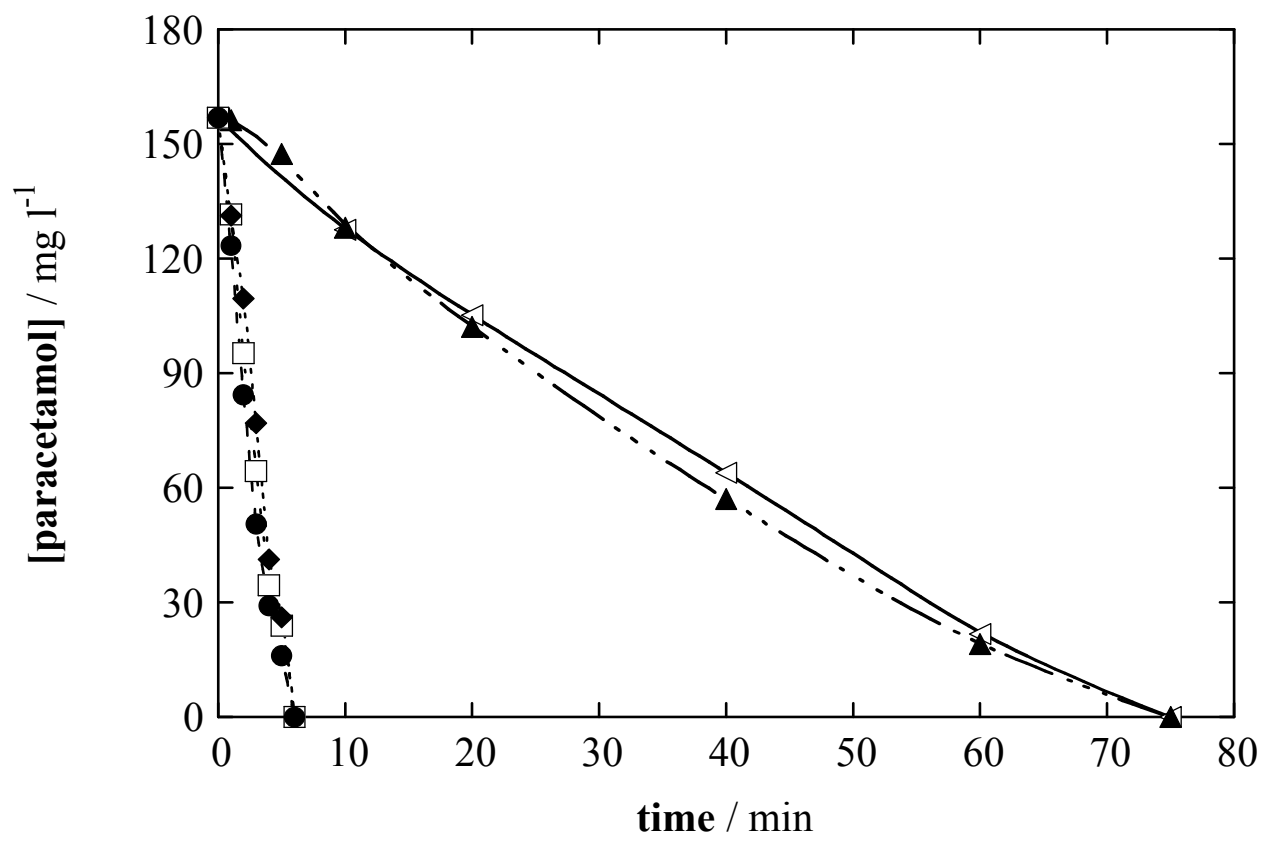

Figure 8. Paracetamol concentration decay for the degradation of $157 \mathrm{mg} \mathrm{L}^{-1}$ paracetamol solutions of $\mathrm{pH} 3.0$ at $100 \mathrm{~mA} \mathrm{~cm}^{-2}$ and at $35.0^{\circ} \mathrm{C}$ using the same cell of Fig. 7 with the following catalysts: $(\triangleleft)$ none , $(\boldsymbol{\Delta}) 1.0 \mathrm{mM} \mathrm{Cu}^{2+}+$ UVA light, $(\square) 1.0$ $\mathrm{mM} \mathrm{Fe}{ }^{2+},(\bullet) 1.0 \mathrm{mM} \mathrm{Fe}^{2+}+\mathrm{UVA}$ light and $(\bullet) 1.0 \mathrm{mM} \mathrm{Fe}^{2+}+1.0 \mathrm{mM} \mathrm{Cu}^{2+}+\mathrm{UVA}^{-}$ light.

The initial nitrogen of paracetamol is lost in the form of $\mathrm{NH}_{4}^{+}$ion, which is quickly accumulated during the early stages of all treatments, as can be seen in Fig. 9a. A minor portion of $\mathrm{NO}_{3}{ }^{-}$is also formed, as detected by ion chromatography. Note that higher $\mathrm{NH}_{4}^{+}$concentration is produced with increasing the oxidation ability of the method, due to the faster mineralization of some N-containing intermediates at the early stages of the degradation process.

Reversed-phase chromatograms of treated paracetamol solutions displayed peaks related to hydroquinone and $p$-benzoquinone as main primary products. Fig. $9 \mathrm{~b}$ shows that they are present in the medium while the initial drug persists in it. Both organics are quickly formed and destroyed at similar rate in the processes catalyzed by $\mathrm{Fe}^{2+}$, indicating that they are mainly destroyed by ${ }^{\circ} \mathrm{OH}$ without significant photodegradation by UVA light.

The behavior of generated carboxylic acids such as ketomalonic, maleic, fumaric, oxalic and oxamic, detected in treated solutions by ion-exclusion chromatography, is very different. As can be seen in Fig. 9c, ketomalonic acid is not totally removed in the treatments without $\mathrm{Fe}^{2+}$, but it is rapidly oxidized to oxalic acid in $40 \mathrm{~min}$ in the presence of $\mathrm{Fe}^{2+}$. Fig. 9c also shows that maleic acid is always completely converted into oxalic acid. Similar results were found for fumaric acid, indicating that all these acids are mainly oxidized by ${ }^{\circ} \mathrm{OH}$ formed from Fenton's reaction (1). 

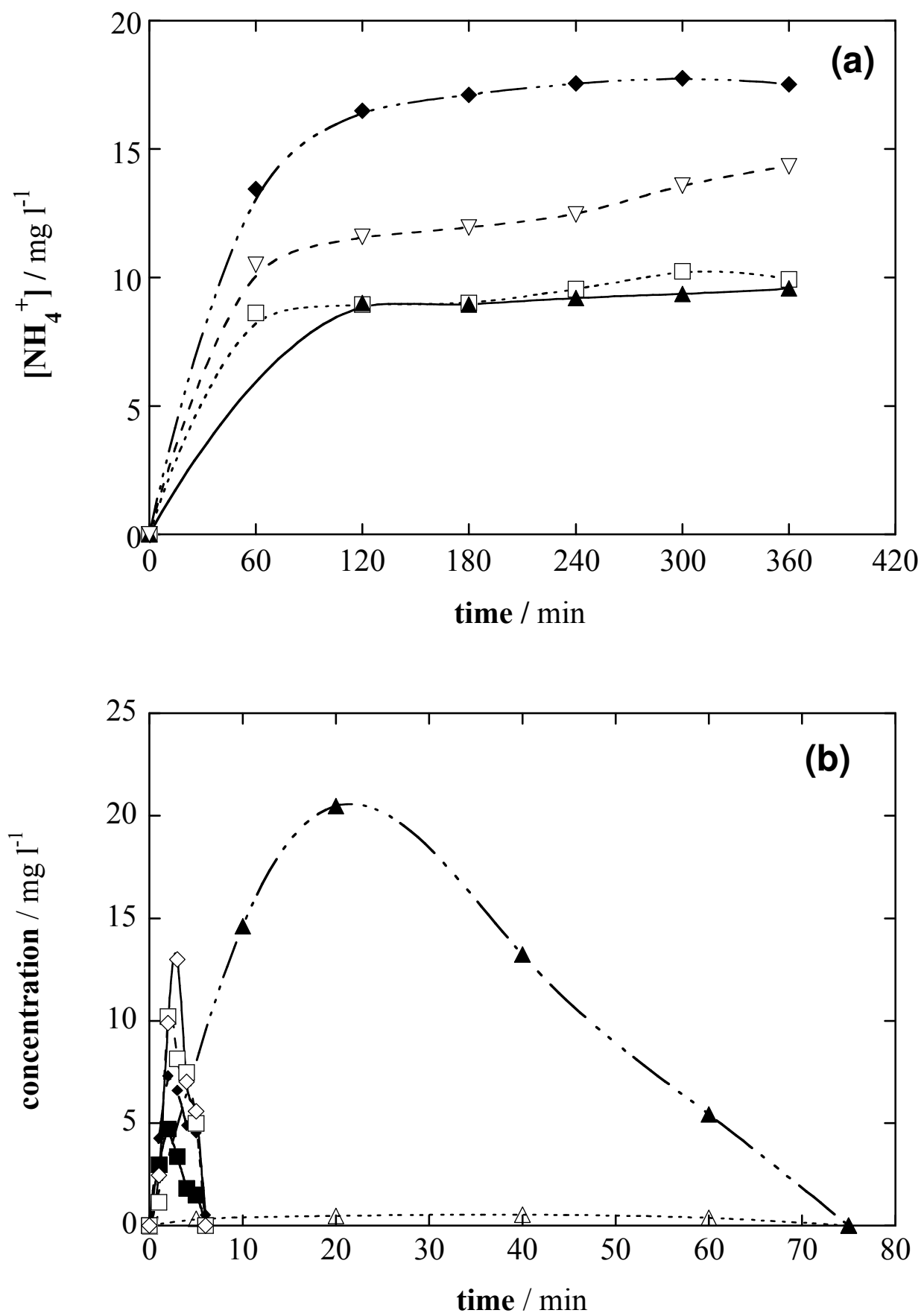

Figure 9. Time-course of the concentration of intermediates detected during the degradation of $157 \mathrm{mg} \mathrm{L}^{-1}$ paracetamol solutions of $\mathrm{pH} 3.0$ at $100 \mathrm{~mA} \mathrm{~cm}$ and at 35.0 ${ }^{\circ} \mathrm{C}$ using the following catalysts: $(\Delta, \mathbf{\Delta}) 1.0 \mathrm{mM} \mathrm{Cu}^{2+}+\mathrm{UVA}$ light, $(\square, \boldsymbol{\square}) 1.0 \mathrm{mM} \mathrm{Fe}^{2+}$ and $(\diamond, \diamond) 1.0 \mathrm{mM} \mathrm{Fe}^{2+}+1.0 \mathrm{mM} \mathrm{Cu}{ }^{2+}+$ UVA light. Plots correspond to: (a) ammonium ion, (b) $(\Delta, \square, \diamond)$ hydroquinone and $(\boldsymbol{\Lambda}, \mathbf{\square}, \diamond) p$-benzoquinone. 

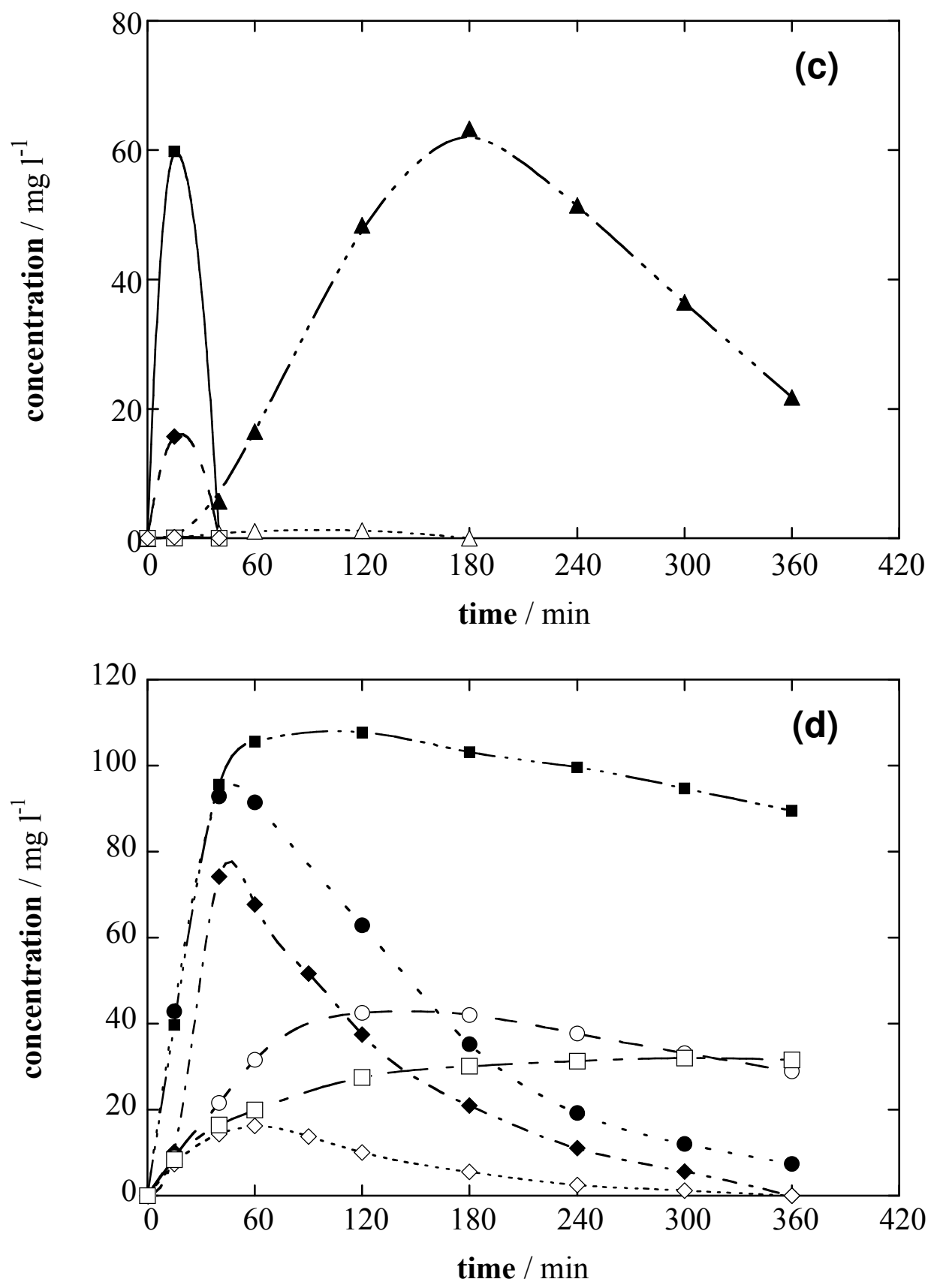

Figure 9. Time-course of the concentration of intermediates detected during the degradation of $157 \mathrm{mg} \mathrm{L}^{-1}$ paracetamol solutions of $\mathrm{pH} 3.0$ at $100 \mathrm{~mA} \mathrm{~cm}$ and at 35.0 ${ }^{\circ} \mathrm{C}$ using the following catalysts: $(\Delta, \boldsymbol{\Delta}) 1.0 \mathrm{mM} \mathrm{Cu}^{2+}+\mathrm{UVA}$ light, $(\square, \boldsymbol{\square}) 1.0 \mathrm{mM} \mathrm{Fe} \mathrm{m}^{2+}$ and $(\diamond, \diamond) 1.0 \mathrm{mM} \mathrm{Fe}^{2+}+1.0 \mathrm{mM} \mathrm{Cu}^{2+}+$ UVA light. Plots correspond to: (c) $(\Delta, \square, \diamond)$ maleic and $(\boldsymbol{\Lambda}, \boldsymbol{\square}, \boldsymbol{\diamond})$ ketomalonic acids and (d) $(\Delta, \square, \diamond)$ oxamic and $(\boldsymbol{\Lambda}, \boldsymbol{\square}, \diamond)$ oxalic acids.

In contrast, Figure 9d evidences that the destruction of oxalic and oxamic acids depends on the catalyst used. Both acids are completely mineralized in the photoelectro-Fenton process with $\mathrm{Cu}^{2+}$, where their $\mathrm{Cu}^{2+}$ and $\mathrm{Fe}^{3+}$ complexes are competitively formed. This can be associated with the oxidation of $\mathrm{Cu}^{2+}$-oxalato and $\mathrm{Cu}^{2+}$-oxamato complexes with ${ }^{\circ} \mathrm{OH}$ in parallel with the photodecomposition of their $\mathrm{Fe}^{3+}$ complexes by UVA light. 


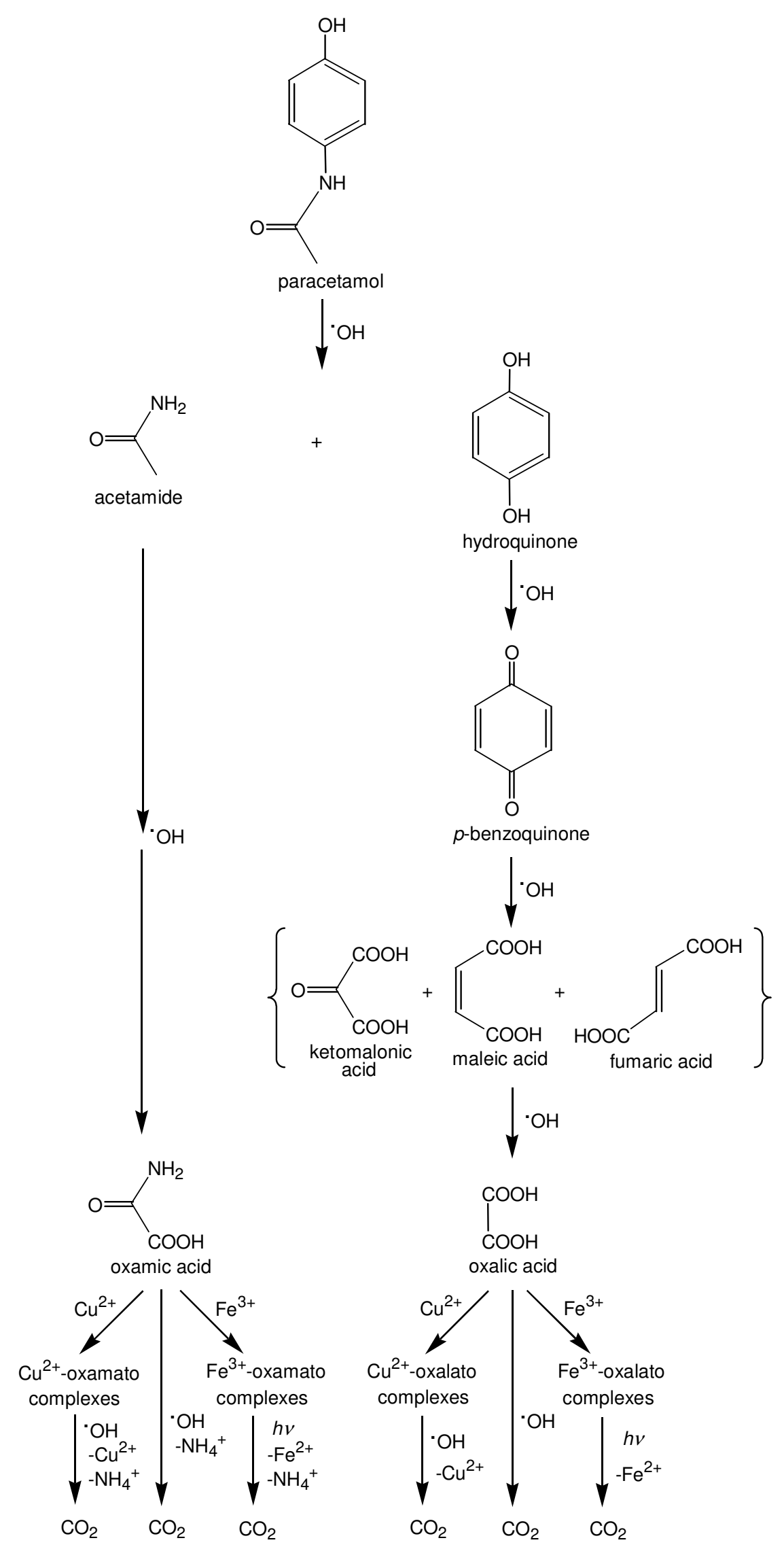

Figure 10. Proposed reaction sequence for the degradation of paracetamol by indirect electrooxidation methods with $\mathrm{H}_{2} \mathrm{O}_{2}$ electrogeneration. 
Fig. 10 presents a proposed pathway for paracetamol degradation by the indirect electrooxidation methods involving all intermediates detected. The initial attack of ${ }^{\circ} \mathrm{OH}$ on the $\mathrm{C}-\mathrm{N}$ bond of this compound yields acetamide and hydroquinone. Further oxidation of hydroquinone leads to $p$-benzoquinone. This product is subsequently degraded to a mixture of ketomalonic, maleic and fumaric acids, which are transformed into oxalic acid. Parallel oxidation of acetamide gives oxamic acid. Final oxalic and oxamic acids are slowly mineralized to $\mathrm{CO}_{2}$ with 'OH. However, this radical is able to oxidize their $\mathrm{Cu}^{2+}$ complexes, but it can not destroy their $\mathrm{Fe}^{3+}$ complexes, which can only be photodecarboxylated under UVA irradiation. These processes involve the formation of $\mathrm{CO}_{2}$, along with the release of $\mathrm{Fe}^{2+}, \mathrm{Cu}^{2+}$ and $\mathrm{NH}_{4}^{+}$.

\section{Conclusions}

It has been demonstrated that EAOPs are useful for the degradation of aromatic drugs and can be applied to the treatment of wastewaters containing these pollutants. Anodic oxidation is only effective when a BDD anode is used due to the efficient production of oxidant ${ }^{\circ} \mathrm{OH}$ from reactions (3) or (15), whereas a $\mathrm{Pt}$ anode with lower oxidizing power leads to quite poor mineralization. The use of indirect electrooxidation methods with $\mathrm{H}_{2} \mathrm{O}_{2}$ electrogeneration yields a faster degradation of aromatic drugs, although total mineralization is more rapidly attained in the photoelectro-Fenton process with $\mathrm{Cu}^{2+}$ in which the high amount of ${ }^{\circ} \mathrm{OH}$ produced from Fenton's reaction can oxidize the complexes of $\mathrm{Cu}^{2+}$ with final carboxylic acids such as oxalic and oxamic, in parallel to the photolysis of their $\mathrm{Fe}^{3+}$ complexes under the action of UVA light. This method is more potent than photoelectro-Fenton, where complexes of $\mathrm{Fe}^{3+}$ with final carboxylic acids are formed, and electro-Fenton in which these complexes can not be destroyed by ${ }^{\circ} \mathrm{OH}$. EAOPs are then environmentally friendly electrochemical methods for wastewater remediation, allowing an effective mineralization of organic pollutants to $\mathrm{CO}_{2}$ and inorganic ions and the recovery of metallic catalysts for their further reuse. The present work also evidences that combination of catalysts $\mathrm{Fe}^{2+}, \mathrm{Cu}^{2+}$ and UVA light in catalyzed ozonation also leads to total decontamination of drug solutions.

\section{Acknowledgements}

Financial support from MEC (Ministerio de Educación y Ciencia, Spain) under project CTQ2004-01954/BQU is acknowledged. 


\section{Resumen}

Actualmente se están desarrollando métodos químicos (AOPs) y electroquímicos (EAOPs) de oxidación avanzada que son capaces de destruir contaminantes orgánicos en aguas. Estas técnicas están basadas en la producción del radical hidroxilo ( $\left.{ }^{\circ} \mathrm{OH}\right)$ como oxidante. En los AOPs el radical ${ }^{\circ} \mathrm{OH}$ se puede obtener a partir de la reacción de Fenton entre el $\mathrm{Fe}^{2+}$ y el $\mathrm{H}_{2} \mathrm{O}_{2}$ adicionados al medio, de la fotorreducción de especies de $\mathrm{Fe}^{3+}$ o bien de la reacción entre el ozono y el $\mathrm{Fe}^{2+}$. En los EAOPs dicho radical se forma a partir de la oxidación del agua en la superficie de un ánodo de elevado sobrepotencial de $\mathrm{O}_{2}$ y/o de la reacción de Fenton entre el $\mathrm{Fe}^{2+}$ añadido al medio y el $\mathrm{H}_{2} \mathrm{O}_{2}$ electrogenerado en el cátodo por la reducción bielectrónica del $\mathrm{O}_{2}$. El presente trabajo describe la mineralización de algunos fármacos aromáticos como el paracetamol, el ibuprofeno, el ácido clofíbrico y el ácido salicílico usando AOPs basados en la ozonización catalizada por $\mathrm{Fe}^{2+}, \mathrm{Cu}^{2+}$ y/o luz UVA y EAOPs como la oxidación anódica, el electro-Fenton y el fotoelectro-Fenton, que son métodos electroquímicos compatibles con el medio ambiente. Para los últimos procesos, se ha estudiado la desaparición de los fármacos con el tiempo y la evolución de los intermedios aromáticos y de los ácidos carboxílicos generados. La oxidación anódica sólo es efectiva cuando se utiliza un ánodo de diamante dopado con boro (BDD), mientras que el proceso fotoelectro-Fenton con $\mathrm{Fe}^{2+}, \mathrm{Cu}^{2+}$ y luz UVA es el método más potente para destruir totalmente los fármacos. El uso conjunto de los catalizadores $\mathrm{Fe}^{2+}$, $\mathrm{Cu}^{2+}$ y luz UVA en la ozonización catalizada también conduce a la descontaminación total de las disoluciones de fármacos.

Palabras clave: fármacos, ozonización, catálisis, oxidación anódica, electrodo de diamante dopado con boro, electro-Fenton, fotoelectro-Fenton.

\section{References}

1. T.A. Ternes, Water Res. 32 (1998) 3245.

2. C.G. Daughton, T.L. Jones-Lepp (Eds.), Pharmaceuticals and Personal Care Products in the Environment. Scientific and Regulatory Issues, ACS Symposium Series, Washington, 2001.

3. C.G. Daughton, T.A. Ternes, Environ. Health Perspect. 107 (1999) 907.

4. J. Skinner, Waste Manag. Res. 9 (1990) 55.

5. D. Pletcher, Acta Chem. Scan. 53 (1999) 745.

6. D. Peterson, D. Watson, W. Winterlin, Bull. Environ. Contam. Toxicol. 44 (1990) 744.

7. D. Vogna, R. Marotta, A. Napolitano, M. D’Ischia, J. Org. Chem. 67 (2002) 6143.

8. W. Glaze, Y. Lay, J. Kang, Ind. Eng. Chem. Res. 34 (1995) 2314.

9. R. Andreozzi, V. Caprio, R. Marotta, D. Vogna, Water Res. 37 (2003) 992.

10. G.R. Peyton, W.H. Glaze, Environ. Sci. Technol. 22 (1988) 761. 
11. R. Andreozzi, R. Marotta, J. Hazar. Mat. 69 (1999), 303.

12. W.H. Glaze, J.W. Kang, D.H. Chapin, Ozone Sci. Eng. 9 (1987) 335.

13. F.J. Beltran, Ozone-UV radiation-hydrogen peroxide oxidation technologies, in: M. Tarr (Ed.), Chemical Degradation Methods for Wastes and Pollutants, Environmental and Industrial Applications, Marcel Dekker, New York, 2003, pp. 1-74.

14. C. Zwiener, F.H. Frimmel, Water Res. 34 (2000) 1881.

15. D.L. Sedlak, J. Hoigné, M.M. David, R.N. Colvile, E. Seyffer, K. Acker, W. Wiepercht, J.A. Lind, S. Fuzzi, Atmospheric Environ. 31 (1997) 2515.

16. B. Kasprzyk-Hordern, M. Ziólek, J. Nawrocki, Appl. Catal. B: Environ. 46 (2003) 639.

17. E. Brillas, P.L. Cabot, R.M. Rodríguez, C. Arias, J.A. Garrido, R. Oliver, Appl. Catal. B: Environ. 51 (2004) 117.

18. M. Skoumal, P.L. Cabot, F. Centellas, C. Arias, R.M. Rodríguez, J.A. Garrido, E. Brillas, Appl. Catal. B: Environ. 66 (2006) 228.

19. Y. Zuo, J. Hoigné, Environ. Sci. Technol. 26 (1992) 1014.

20. J.J. Pignatello, Environ. Sci. Technol. 26 (1992) 944

21. Y. Sun, J.J. Pignatello, Environ. Sci. Technol. 27 (1993) 304.

22. L. Kaba, G.D. Hitchens, J.O’M. Bockris, J. Electrochem. Soc. 137 (1990) 1341.

23. O.J. Murphy, G.D. Hitchens, L. Kaba, C.E. Verotsko, Water Res. 26 (1992) 443.

24. B. Marselli, J. Garcia-Gomez, P.A. Michaud, M.A. Rodrigo, Ch. Comninellis, J. Electrochem. Soc. 150 (2003) D79.

25. R.A. Torres, W. Torres, P. Peringer, C. Pulgarin, Chemosphere 50 (2003) 97.

26. E. Brillas, P.L. Cabot, J. Casado, Electrochemical methods for degradation of organic pollutants in aqueous media, in: Tarr, M. (Ed.). Chemical degradation methods for wastes and pollutants. Environmental and industrial applications, Marcel Dekker, New York, 2003, pp. 235304.

27. J.D. Rodgers, N.J. Bunce, Environ. Sci. Technol. 35 (2001) 406.

28. Ch. Comninellis, A. De Battisti, J. Chim. Phys. 93 (1996) 673.

29. Z.C. Wu, M.H. Zhou, Environ. Sci. Technol. 35 (2001) 2698.

30. F. Bonfatti, S. Ferro, F. Lavezzo, M. Malacarne, G. Lodi, A. De Battisti, J. Electrochem. Soc. 146 (1999) 2175.

31. S.K. Johnson, L.L. Houk, J. Feng, R.S. Houk, D.C. Johnson, Environ. Sci. Technol. 33 (1999) 2638.

32. D. Gandini, E. Mahé, P.A. Michaud, W. Haenni, A. Perret, Ch. Comninellis, J. Appl. Electrochem. 30 (2000) 1345.

33. E. Brillas, I. Sirés, C. Arias, P.L. Cabot, F. Centellas, R.M. Rodríguez, J.A. Garrido, Chemosphere 58 (2005) 399.

34. J.S. Do, C.P. Chen, J. Electrochem. Soc. 140 (1993) 1632.

35. C. Ponce de Leon, D. Pletcher, J. Appl. Electrochem. 25 (1995) 307.

36. A. Alvarez-Gallegos, D. Pletcher, Electrochim. Acta 44 (1999) 2483.

37. M.A. Oturan, J. Appl. Electrochem. 30 (2000) 475. 
38. B. Gözmen, M.A. Oturan, N. Oturan, O. Erbatur, Environ. Sci. Technol. 37 (2003) 3716.

39. A. Wang, J. Qu, J. Ru, H. Liu, J. Ge, Dyes Pigments 65 (2005) 225.

40. E. Brillas, B. Boye, I. Sirés, J.A. Garrido, R.M. Rodríguez, C. Arias, P.L. Cabot, Ch. Comninellis, Electrochim. Acta 49 (2004) 4487.

41. E. Brillas, M.A. Baños, J.C. Calpe, B. Boye, J.A. Garrido, Chemosphere 51 (2003) 227.

42. E. Brillas, M.A. Baños, S. Camps, C. Arias, P.L. Cabot, J.A. Garrido, R.M. Rodríguez, New J. Chem. 28 (2004) 314.

43. I. Sirés, C. Arias, P.L. Cabot, F. Centellas, R.M. Rodríguez, J.A. Garrido, E. Brillas, Environ. Chem. 1 (2004) 26.

44. A. Da Pozzo, C. Merli, I. Sirés, J.A. Garrido, R.M. Rodríguez, E. Brillas, Environ. Chem. Lett. 3 (2005) 7.

45. I. Sirés, J.A. Garrido, R.M. Rodríguez, P.L. Cabot, F. Centellas, C. Arias, E. Brillas, J. Electrochem. Soc. 153 (2006) D1.

46. $\quad$ Y. Pi, J. Schumacher, M. Jekel, Water Res. 39 (2005) 83.

47. J. De Laat, H. Gallard, Environ. Sci. Technol. 33 (1999) 2726. 